\title{
Vitamin D deficiency in patients with acute coronary syndrome: clinically relevant or just a bystander?
}

\section{Marijana Knežević Praveček*, \\ Irzal Hadžibegović, Katica Cvitkušić Lukenda, \\ Antonija Raguž, Ivica Dunđer, Krešimir Gabaldo, Đeiti Prvulović, Božo Vujeva}

General Hospital "Dr. J. Benčević" Slavonski Brod, Slavonski Brod, Croatia

RECEIVED:

August 11, 2015

ACCEPTED:

September 17, 2015

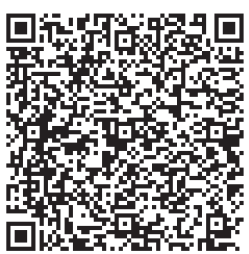

$\square$ Cardiologia Croatica 2015;10(9-10):204.
KEYWORDS: acute coronary syndrome; coronary angiography; 25-hydroxyvitamin D; diabetes; Vitamin D deficiency.

CITATION: Cardiol Croat. 2015;10(9-10):204. | DoI: http://dx.doi.org/10.15836/ccar.2015.204

*ADDRESS FOR CORRESPONDENCE: Marijana Knežević Praveček, Opća Bolnica „Dr.J. Benčević“ Slavonski Brod, Andrije Štampara 42, HR-35000 Slavonski Brod, Croatia. / Phone: +385-98-550-325 / E-mail: marijana@aip.hr

ORCID: Irzal Hadžibegović, http://orcid.org/0000-0002-3768-9134 • Krešimir Gabaldo, http://orcid.org/0000-0002-0116-5929 Đeiti Prvulović, http://orcid.org/0000-0002-8041-1197 • Božo Vujeva, http://orcid.org/0000-0003-0490-3832

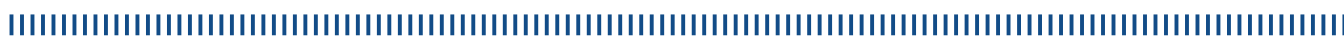

AIM: The goal of this study was to determine, for the first time in an east European country, the relationship of 25-hydroxyvitamin D (25(OH)D) serum concentration with extent of coronary artery disease and prognosis in patients with acute coronary syndrome (ACS) during a three-year follow up period. ${ }^{1-3}$

PATIENTS AND METHODS: The study included 60 ACS patients hospitalized at cardiology department for ACS between March 2012 and September 2012; and 60 matched controls without ACS. Standard laboratory testing and vitamin D determination were performed in all study patients. In addition, ACS patients underwent coronary angiography and were followed-up for 36 months of ACS for major adverse cardiac events (MACE).

RESULTS: Patients with ACS had a statistically significant lower mean 25(OH)D level as compared with control group ( $35.19 \mathrm{nmol} / \mathrm{L}$ vs. $58.08 \mathrm{nmol} / \mathrm{L}, \mathrm{p}<0.001)$. The lowest mean level of 25(OH)D was recorded in diabetic patients with ACS $(30.45 \mathrm{nmol} / \mathrm{L})$. After coronary angiography, ACS patients were divided into three subgroups regarding coronary disease severity: single, double and multiple vessel disease with 25(OH)D serum levels of $36.44 \mathrm{nmol} / \mathrm{L}, 33.65 \mathrm{nmol} / \mathrm{L}$ and $31.70 \mathrm{nmol} / \mathrm{L}$, respectively. Event free survival rate at 36 months in the ACS group was 60\%. Patients with a MACE had lower 25(OH)D, but that difference was not statistically significant (32.64 nmol/L vs $37.01 \mathrm{nmol} / \mathrm{L}$ in event free patients).

CONCLUSION: There is an association between low serum concentration of 25(OH)D and ACS. Vitamin $\mathrm{D}$ level is considerably influenced by diabetes comorbidity. There was no significant association between 25(OH)D and MACE at 36 months in ACS patients.

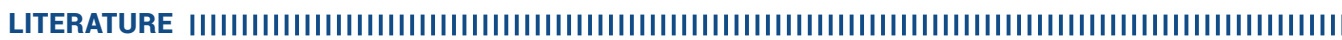

1. Naesgaard PA, Pönitz V, Aarsetoey H, Brügger-Andersen T, Grundt H, Harris WS, et al. Prognostic utility of vitamin D in acute coronary syndrome patients in coastal Norway. Dis Markers. 2015;2015:283178. DOI: http://dx.doi.org/10.1155/2015/283178

2. Belen E, Tipi FF, Aykan AC, Findikçioğlu U, Karakuş G, Yeșil A, et al. Clinical staging in chronic heart failure associated with low vitamin D and elevated parathormone levels. Acta Cardiol. 2014;69:665-71. DOI: http://dx.doi.org/10.2143/AC.69.6.1000009

3. Kienreich K, Tomaschitz A, Verheyen N, Pieber T, Gaksch M, Grübler MR, et al. Vitamin D and cardiovascular disease. Nutrients. 2013;5:3005-21. DOI: http://dx.doi.org/10.3390/nu5083005 